\title{
The Influence of Customer Commitment and Loyalty Program on Customer Advocacy Behavior in B2B Product
}

\author{
Bariky Robby $^{1}$, Lilik Noor Yuliati ${ }^{2}$, Megawati Simanjuntak ${ }^{3}$ \\ ${ }^{1}$ Bogor Agricultural University, Faculty of Management and Business, Bogor, Indonesia \\ ${ }^{2,3}$ Bogor Agricultural University, Faculty of Human Ecology, Bogor, Indonesia
}

\begin{abstract}
This paper empirically examines the impact of satisfaction and trust on commitment, and explore the effect of commitment on customer advocacy behaviors. The other purpose of this paper also investigate the moderating influence of B2B loyalty program toward supporting customer advocacy and consumer commitment in the context of Indonesia's cement sector. The hypothesis framework was developed to assess linkage between customer relationship commitment according trust and satisfaction, also investigate the moderating influence of B2B loyalty programs toward supporting customer advocacy behaviors, including sharing information, marketing research support, word-of-mouth referrals, and increasing repatronage. The model was developed and tested on 148 Building material retailer who become an active customer of the biggest cement manufacture in Indonesia. Assessments of loyalty program effect was conducted by multi-group analysis and Independent T-test. The result reveal a significant impact of consumer trust on consumer commitment and a significant impact of customer commitment on several consumer advocacy behavior. B2B loyalty program membership shows significant moderating effect on several hypothesis framework.
\end{abstract}

Keywords: commitment, customer advocacy behavior, loyalty program, relationship marketing, satisfaction, trust.

\section{Introduction}

The development of brand awareness and maintaining relationship with customers are two ways to keep the power of the brand for the Business to Business company [1]. These two ways will generate high profit of the revenue for the company both in the short term and the long term [2]-[4]. For a manufacturing company that already has a strong brand and a big market share, establishing a good relationship with the working partners is expected to increase the effectiveness and efficiency in the supply chain [5]. Maintaining the trust and satisfaction of performance is one of the requirements of healthy long-term relationship [6], [7]. The concept of Customer Relation Management (CRM) is said to be able to increase the age of the customer or called Customer Lifetime Value (CLV) [8].

In the development, there are few studies which begin to consider the concept of CRM which is applied in Business to Business (B2B) relationship, one of them is in the form of customer loyalty programs. Customer loyalty program is a tool for company to retain profitable customers for them by offering incentives [9]. In the perspective of $\mathrm{B} 2 \mathrm{~B}$, loyalty program is not only associated with purchasing behavior but also the behavior of advocacy done by the customers. Customer advocacy behavior is shown by the behavior of sharing information, marketing research support, word of mouth and increased repatronage intention [8].

Based on the explanation that have been given above, it leads the idea to do research to study the effect of customer commitment and their will in doing advocacy activity as well as study the influence of B2B loyalty program in supporting customer advocacy behavior. Customer commitment will not be formed by itself. Customer trust and satisfaction become two factors in the growth of customer commitment [8], [10], [11], [12]. From the above explanation, it can be formulated the following questions:

1) How does the effect of satisfaction on customer trust?

2) How does the effect of trust and satisfaction on the customer commitment?

3) How does the effect of commitment on the customer advocacy behavior?

4) How does the effect of loyalty program on the form of the customer advocacy behavior?

\section{Literature Review}

The concept of relationship quality has arisen from theory and research of relationship marketing [12]. The objective of relationship quality is to enforce the existing relationship and convert ordinary customer into loyal ones. In the previous research of relationship quality, many researcher has discussed and tested the model of relationship quality in various context, every researcher had a different definition about relationship quality. However, we agree that the concept of relationship quality is a high-order construct which consist of several distinct but related components or dimensions. These dimensions are Opportunism [13], trust in salesperson [14], trust [8], satisfaction [14], commitment [13] and perceived quality [11]. According previous research, this study propose that relationship quality built of three related dimension, which are: trust, satisfaction, and commitment. The selection of these dimensions is based on the literature and suitability to the context of B2B market [10], [15], [16], [17]. 


\section{International Journal of Science and Research (IJSR) \\ ISSN (Online): 2319-7064}

Index Copernicus Value (2015): 78.96 | Impact Factor (2015): 6.391

\subsection{Satisfaction, Trust, and Commitment}

Trust is considered as an essential foundation for building and maintaining successful relationships, it builds when the customer has confidence in a service provider's reliability and integrity [15]. Trust as a critical success factor in successful service relationship in B2B markets [18]. The customer should feel safe in dealing transaction with supplier or provider and need to be assured that their transaction is confidential. In other words, Trust is customer's belief that a firm is reliable, stand by it word and fulfills its promised obligations. Past research has shown a link between trust and customer commitment, also link between trust and satisfaction. Similar with trust, commitment is viewed as an important foundation in successful relationships [15]. The concept of commitment in relation quality came from industrial and organizational psychology and has been implemented on marketing relationship context [19]. In the buyer-and-seller relationship literature stated that commitment defined as an implicit and explicit pledge of relationship continuity between buyers and sellers [10]. Consistent with other research about relationship marketing research trust is modeled, as a precursor to commitment. As part of this model, B2B loyalty program membership is anticipated to positively moderate this relationship because committed customers receive greater assurances that they stand to benefit by their loyalty program participation [20].

- H1a Customer's trust is positively related to commitment

- H1b Loyalty program membership positively moderates the effect between trust and commitment

The relationship between satisfaction and commitment have been identified in a number of different field. Employee satisfaction influence the affective and instrumental commitment to the organization [21]. Satisfactory exchange is a part of affective and temporal commitment in a marketing context [22]. In other words, when consumer are satisfied with their experience with the service organization, they are more likely to be committed to that organization. Thus, if consumer have already invested time and effort to use a service organization and they feel positive experience, they will want to stay with the same organization rather than invest time and effort again to finding another one.

- H2a Customer's satisfaction is positively related to Commitment

- H2b Loyalty program membership positively moderates the effect between satisfaction and commitment.

Satisfaction is considered as the positive affective state resulting from an evaluation of consumer's expectation prior to purchase and consumption experience. In the context of relational exchange between firms in b2b market, satisfaction transmit the idea that no opportunistic behaviors occur and that one party's actions are subject to the well-being of the other [23]. From this perspective, satisfaction contributes to the formation of trust. Satisfaction is defined as an overall evaluation based on the total purchase or consumption experience of goods or services over time. Satisfaction is an important variable in business relationships and partner should ensure satisfaction during each business transaction. Customer who more satisfied with transaction process in the past, customer will trust the seller for the future of relationship [24]. The other finding which support the link between satisfaction and trust said that satisfaction have a positive link into perceptions of suppliers' benevolence and credibility (which are seen as dimensions of trust) [25]. In the context of B2B Loyalty program, Satisfaction of consumer in retail loyalty program is positively related to program trust [17].

- H3a Customer's satisfaction is positively related to trust

- H3b Loyalty program membership positively moderates the effect between satisfaction and trust

\subsection{Customer Advocacy}

Commitment is considered as an enduring desire to maintain a valued relationship [11]. Committed relationship partner are unlikely to switch although a competing supplier offer a better value. Consequently, a strength of commitment help to stabilize the relationship. Sustaining customer relationship also require more resources than ongoing marketing exchanges. Customer advocates are important sources for future revenue and market intelligence as they offer insight it's an opportunity for firms to manage product, pricing, distribution channels, and marketing communication. Customer advocacy reflect combinations of marketing resources that contribute to a more efficient and effective marketing enterprise, including voluntarily sharing customer information, engaging firm marketing research, word-ofmoth referrals and increasing level and proportions of purchase activity [8].

Information sharing is introduced in this study as the willingness of business customer to voluntarily provide specific internal business information that can be used to maintain and develop customer relationship. The internal business information can be used by firm to develop of customized products and services [26]. Although, for getting the specific information need a deep personalized communication and trust between firm and customer. Customer are predicted to be willing to share specific business information when they are committed to requestor firm. Furthermore, customer who enroll the B2B loyalty program already give some data information to the firm. Hence, loyalty program membership is anticipated to moderate the relationship between commitment and information sharing behaviors

- H4a Customer's Commitment is positively related to information sharing

- H4b Loyalty program membership positively moderates the effect between Commitment and information sharing

Marketing research support is introduced in this study as the willingness of business customer to contribute the research of firm about their product, services and marketing activities. Making suggestion for firm improvement, giving feedback about new firm offer, and sharing about unfulfilled need to firm. Since customer input is fundamental to the marketing concept, active customer participation is necessary for collaborative marketing relationship and B2B loyalty programs are a media facilitator for customer participation. Customer loyalty programs have been shown to raise the 


\section{International Journal of Science and Research (IJSR) \\ ISSN (Online): 2319-7064}

Index Copernicus Value (2015): 78.96 | Impact Factor (2015): 6.391

level of voluntary customer feedback via marketing research requests [20]. Thus, committed customers are anticipated to willingly provide marketing research support and loyalty program membership is anticipated to moderate this relationship.

- H5a Customer's Commitment is positively related to marketing research support

- H5b Loyalty program membership positively moderates the effect between Commitment and marketing research support

Word of mouth referrals is the recommendations from one individual to other individual regarding a firm and it's product or services. Word-of-mouth is well understood as a credible source of communication and plays an instrumental role in new customer acquisitions [27]. Committed customer will promote the supplying firm through word-of-mouth referrals, and loyalty program membership is anticipated to moderate this relationship [28].

- H6a Customer's Commitment is positively related to marketing research support

- H6b Loyalty program membership positively moderates the effect between Commitment and marketing research support

Repatronage intention refers to the individual judgment about buying again a designated service from the same firm. In the marketing literature, there is wide agreement that repurchase as the key behavioral outcome for relationship marketing success [29]. Proportion of purchases devoted to a single entity is well entrenched in the marketing literature as a manifestation of committed customer behavior. In this studies, committed customer are not just expected maintain the relationship, but also increase the level and proportion of their purchasing activity over time [28]. Loyalty program membership is anticipated to moderate this relationship since these program typically offer higher benefit during proses of purchase.

- H7a Customer's Commitment is positively related to marketing research support

- H7b Loyalty program membership positively moderates the effect between Commitment and marketing research support

\subsection{Research Framework}

The researcher want to know how far the linkage between customer relationship commitment according to trust and satisfaction, also the moderating influence of B2B loyalty programs toward supporting customer advocacy behaviors, including sharing information, marketing research support, word-of-mouth referrals, and increasing repatronage. Model or conceptual framework in the research can be seen in figure 1.

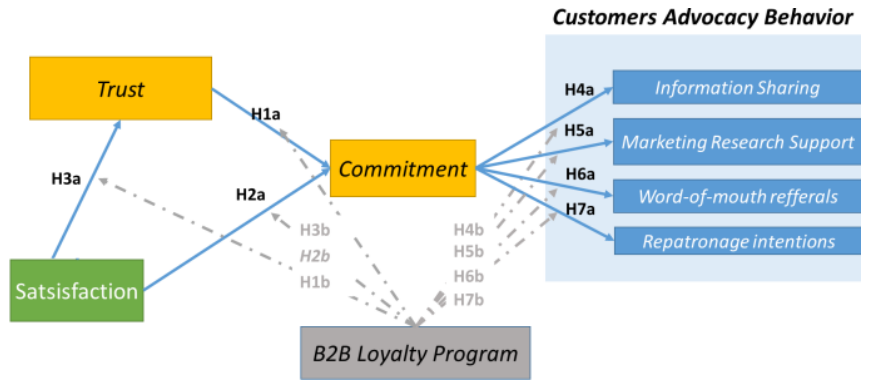

Figure 1: Research framework

\section{Research Methodology}

This research uses quantitative research that aims to calculate the data and usually apply several forms of statistical analysis. The method used in this research is descriptive research design that aims to determine the extent of the variables used in this study is interrelated (Malhotra 2007). This research was conducted in March 2016 to October 2016. The data were collected in May to June 2016, with research sites in Bogor and Bekasi.

Data collection techniques performed in obtaining the necessary data in this research was by using the questionnaire instrument. The way of distributing questionnaires in this study was by spreading the questionnaires to the cement retailers directly to get the assessment of the variables studied. The data collection process in the questionnaire was obtained through the interview process in filling out the questionnaire to the owners of retailer cement. The measurement in this study was using a Likert scale. In order to support the purpose of this research, Customer equally divided into two categories:

- Customer who had been enrolled in the manufacture's B2B loyalty program for a minimum 12 months and already received the reward redemption

- Customer who were not enrolled in the manufacture's loyalty program.

Simple random sampling was conducted on each category and total 149 respondent completely answer the questionnaire. 100 respondents are customer who had been enrolled in the cement manufacture's B2B loyalty program for a minimum 12 months and already received the reward redemption and 49 respondents are Customer who were not enrolled in the chemical manufacture's loyalty program. Before actual data collection, the questionnaire is pre-tested by personally administering it to 20 Customers who had a business relationship with chosen cement manufacture over 1 year. The analysis of data was done using SPSS 22.0.

Structural equation model estimated using LISREL 8.8 was applied to analyze the proposed research hypothesis. In order to analyze the moderating hypotheses, multi-group analysis using LISREL 8.8 was conducted to assess B2B Loyalty Program membership effect on the structural model.The SEM model of the research can be seen in figure 2 .

Volume 6 Issue 7, July 2017 www.ijsr.net 


\section{International Journal of Science and Research (IJSR) \\ ISSN (Online): 2319-7064}

Index Copernicus Value (2015): 78.96 | Impact Factor (2015): 6.391

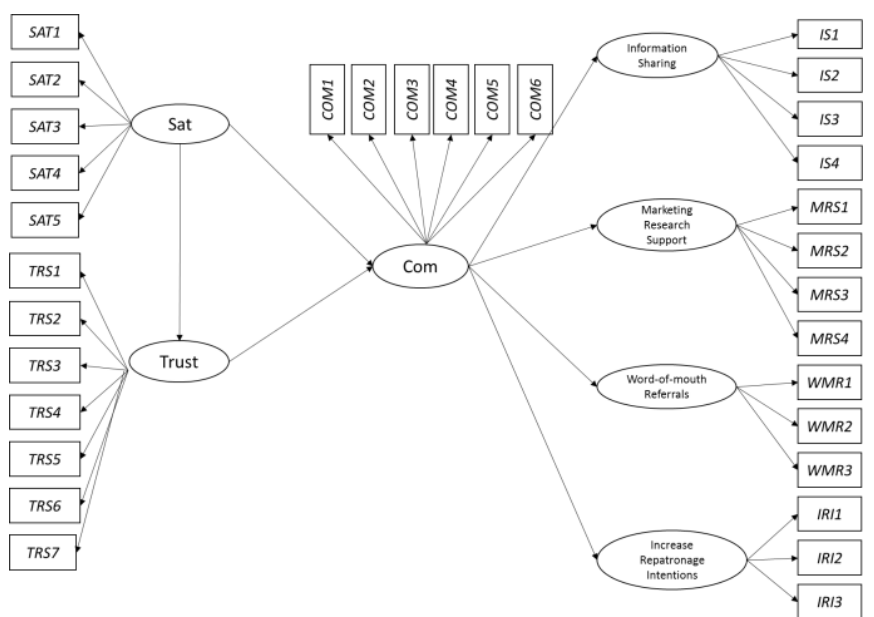

Figure 2: SEM LISREL 8.8 Model of Research

\section{Result}

The measurement model specifies how the latent variable are measured in terms of observed variable. It describes the validities and reliabilities of measurement process. For measuring the model, a ratio of factor loadings to standard error (lambda or loadings) more than 0.5 was classified as reliable. Construct reliability (CR) and Variance Extracted (VE) should be more than 0.7 and 0.5 to have acceptable fit [30] [31].

The result of the Confirmatory factor analysis showed in Table 1. The results indicate that the model are reliable and valid, it showed from the value of $C R$ were above the threshold, it ranged from 0.77 to 0.86 and the variance extracted ranged from 0.5 to 0.64 . The standardized loading factor from each construct were significant, It ranged from 0.55 to 1.01 . So can be concluded that the indicators and the constructs were acceptable.

Table 1: Margin specifications

\begin{tabular}{|c|c|c|c|c|}
\hline Variables & Indicator & \begin{tabular}{|c|} 
Standardized \\
Loading \\
Factor (SLF)
\end{tabular} & $\begin{array}{l}\text { Construct } \\
\text { Reliability } \\
\text { (CR) }\end{array}$ & $\begin{array}{c}\text { Variance } \\
\text { Extracted } \\
\text { (VE) }\end{array}$ \\
\hline \multirow[t]{5}{*}{ Satisfaction } & SAT1 & \begin{tabular}{l|l}
0.87 \\
\end{tabular} & \multirow[t]{3}{*}{0.82} & \multirow[t]{3}{*}{0.5} \\
\hline & SAT2 & 0.74 & & \\
\hline & SAT3 & 0.79 & & \\
\hline & SAT4 & 0.67 & & \\
\hline & SAT5 & 0.55 & & \\
\hline \multirow[t]{4}{*}{ Trust } & TR1 & 0.63 & \multirow[t]{4}{*}{0.78} & \multirow[t]{4}{*}{0.57} \\
\hline & TR2 & 0.72 & & \\
\hline & TR3 & 0.66 & & \\
\hline & TR7 & 0.67 & & \\
\hline \multirow[t]{6}{*}{ Commitment } & COM1 & 0.75 & \multirow[t]{6}{*}{0.82} & \multirow[t]{6}{*}{0.54} \\
\hline & COM2 & 0.77 & & \\
\hline & COM3 & 0.69 & & \\
\hline & COM4 & 0.77 & & \\
\hline & COM5 & 0.7 & & \\
\hline & COM6 & 0.79 & & \\
\hline \multirow{4}{*}{$\begin{array}{c}\text { Information } \\
\text { sharing }\end{array}$} & IS1 & 0.9 & \multirow[t]{4}{*}{0.86} & \multirow[t]{4}{*}{0.61} \\
\hline & IS2 & 0.97 & & \\
\hline & IS3 & 0.91 & & \\
\hline & IS4 & 0.98 & & \\
\hline \multirow{2}{*}{$\begin{array}{l}\text { Marketing } \\
\text { research }\end{array}$} & MRS1 & 0.93 & \multirow[t]{2}{*}{0.77} & \multirow[t]{2}{*}{0.56} \\
\hline & MRS2 & 0.8 & & \\
\hline
\end{tabular}

\begin{tabular}{|c|c|c|c|c|}
\hline \multirow{2}{*}{ support } & MRS3 & 0.66 & \multirow{2}{*}{} & \\
\cline { 2 - 3 } & MRS4 & 0.69 & & \\
\hline \multirow{3}{*}{$\begin{array}{c}\text { Word-of-mouth } \\
\text { referrals }\end{array}$} & WMR1 & 0.81 & 0.72 & 0.57 \\
\cline { 2 - 3 } & WMR2 & 0.73 & & \\
\cline { 2 - 3 } & WMR3 & 0.8 & & \\
\hline $\begin{array}{c}\text { Increased } \\
\text { repatronage } \\
\text { intent }\end{array}$ & IRI1 & 0.93 & 0.78 & 0.64 \\
\cline { 2 - 3 } & IRI2 & 1.01 & & \\
\hline
\end{tabular}

The Result of standardized loading factor and t-value of the model were showed in Table 2. Result from the structural model exhibit acceptable level of fit with X2 $=329$, RMSEA $=0.01, \mathrm{RFI}=0.82, \mathrm{GFI}=0.85, \mathrm{AGFI}=0.82, \mathrm{CFI}=1, \mathrm{NFI}=$ 0.84 , and NNFI $=1$.

The result finds that Customer satisfaction influence customer trust ( $\lambda=4.41, \mathrm{t}=0.82)$. Customer satisfaction also influence customer commitment by indirect relationship through intervening variable customer trust as customer trust is positively related to customer commitment $(\lambda=1.32$, $\mathrm{t}=1.97)$. In support of $\mathrm{H} 4 \mathrm{a}-\mathrm{H} 7 \mathrm{a}$, commitment significantly influences marketing research support $(\lambda=0.59, \mathrm{t}=3.71)$, word-of-mouth referrals $(\lambda=0.8, \mathrm{t}=4.47)$, and increased repatronage intentions $(\lambda=0.51, \mathrm{t}=3.29)$. Customer commitment also influence information sharing but in weaker relationship $(\lambda=0.2, \mathrm{t}=1.81)$

Table 2: Result of Hypotheses

\begin{tabular}{|c|c|c|c|c|}
\hline No & Path & $\begin{array}{c}\text { T- } \\
\text { Value }\end{array}$ & $\begin{array}{c}\text { Standardized } \\
\text { Solution }\end{array}$ & $\begin{array}{c}\text { Hypothesis } \\
\text { supported }\end{array}$ \\
\hline H1a & $\begin{array}{c}\text { Trust -> Customer } \\
\text { Commitment }\end{array}$ & 1.97 & 1.32 & Yes \\
\hline H2a & $\begin{array}{c}\text { Satisfaction-> } \\
\text { Customer } \\
\text { Commitment }\end{array}$ & -0.83 & -0.46 & No \\
\hline H3a & Satisfaction -> Trust & 4.41 & 0.82 & Yes \\
\hline H4a & $\begin{array}{c}\text { Customer } \\
\text { Commitment -> } \\
\text { Information Sharing }\end{array}$ & 1.81 & 0.2 & No \\
$\begin{array}{c}\text { Customer } \\
\text { Commitment -> } \\
\text { Research Support }\end{array}$ & 3.71 & 0.59 & Yes \\
\hline H6a & $\begin{array}{c}\text { Customer } \\
\text { Commitment -> } \\
\text { Word of Mouth } \\
\text { Referrals }\end{array}$ & 4.47 & 0.8 & Yes \\
\hline H7a & $\begin{array}{c}\text { Customer } \\
\text { Commitment -> } \\
\text { Increased Repatronage } \\
\text { Intentions }\end{array}$ & 3.29 & 0.51 & Yes \\
\hline
\end{tabular}

\subsection{Influence of Loyalty Program as Moderating Hypotheses}

In order to investigate the seven moderating hypotheses, multigroup analysis within LISREL 8.8 was conducted to assess B2B loyalty program effect on structural model. The multi-group analysis test was conducted using a two-step approach. The moderating effect of loyalty program was estimated in two steps. In the first step, a multi-group equation model restricted all paths as equal between the two groups. In the second step, the model relaxed the restriction of equal paths and estimated one particular path. Because the second model has one degree of freedom less, a significant

Volume 6 Issue 7, July 2017 www.ijsr.net 


\section{International Journal of Science and Research (IJSR) \\ ISSN (Online): 2319-7064}

Index Copernicus Value (2015): 78.96 | Impact Factor (2015): 6.391

model improvement is reached when the drop in $\chi^{2}$ between the two models for one degree of freedom is higher than 3.84 ( $\mathrm{p} \leq 0.05)$, which means what the two groups are significantly different.

Table 3: Chi square Different Test

\begin{tabular}{|c|c|c|c|c|c|}
\hline Path & $\begin{array}{c}\text { Standardized } \\
\text { Solution } \\
\text { Grup 1 }\end{array}$ & $\begin{array}{c}\text { T- } \\
\text { Value } \\
\text { Grup 1 }\end{array}$ & $\begin{array}{c}\text { Standardized } \\
\text { Solution } \\
\text { Grup 2 }\end{array}$ & $\begin{array}{c}\text { T- } \\
\text { Value } \\
\text { Grup } \\
2\end{array}$ & $\begin{array}{c}\text { Chi } \\
\text { square } \\
\text { Different } \\
\left(\Delta X^{2}\right)\end{array}$ \\
\hline $\begin{array}{c}\text { Trust -> } \\
\text { Customer } \\
\text { Commitment }\end{array}$ & 1.06 & 2.94 & 0.91 & 2.8 & 4.63 \\
\hline $\begin{array}{c}\text { Satisfaction -> } \\
\text { Customer } \\
\text { Commitment }\end{array}$ & -0.3 & -1.09 & 0.16 & 0.62 & 4.6 \\
\hline $\begin{array}{c}\text { Satisfaction -> } \\
\text { Trust }\end{array}$ & 0.75 & 4.07 & 0.75 & 3.52 & 2.22 \\
\hline $\begin{array}{c}\text { Customer } \\
\text { Commitment -> } \\
\text { Information } \\
\text { Sharing }\end{array}$ & 0.16 & 1.35 & 0.13 & 0.79 & 2.46 \\
\hline $\begin{array}{c}\text { Customer } \\
\text { Commitment -> } \\
\text { Research } \\
\text { Support }\end{array}$ & 0.45 & 3.01 & 0.27 & 1.52 & 4.18 \\
\hline $\begin{array}{c}\text { Customer } \\
\text { Commitment -> } \\
\text { Word of Mouth } \\
\text { Referrals }\end{array}$ & 0.75 & 3.91 & 0.57 & 2.98 & 4.56 \\
\hline $\begin{array}{c}\text { Customer } \\
\text { Commitment -> } \\
\text { Increased } \\
\text { Repatronage } \\
\text { Intentions }\end{array}$ & 0.78 & 3.71 & 0.64 & 2.98 & 4.65 \\
\hline
\end{tabular}

The results displayed in Table 3. The chi square difference test show significant result at the level $p<0.05$ between two categories assessing the moderate effect of loyalty program membership. Indeed, non-significant result is found for path from satisfaction to trust and commitment to information sharing.

\subsection{Discussion}

This study found strong evidence that there is a relationship between customer commitment and willingness to behave in customer advocacy without any force. This study found that there is a good relationship between the customer trust and customer commitment (H1a), which is in line with the findings of previous study [32], [9]. In this study also found evidence that there is a strong relationship between the customer satisfaction and customer trust (H3a). The trust in a product or brand is influenced by experience and the results which had been obtained in the past. The experience and the positive results of the satisfaction felt by each customer. One hypothesis which was not proven in this research is the influence of satisfaction on customer commitment (H2a). From the hypothesis $\mathrm{H} 2 \mathrm{a}$ and $\mathrm{H} 3 \mathrm{a}$, it was shown that satisfaction had no direct effect on the commitment; trust is moderating variables from the relationship between customer satisfaction and commitment. It was supported by the evidence of the result of SEM analysis where the value of the indirect weighting standard was 1.08 . This indirect effect is the effect of customer satisfaction on customer satisfaction through customer trust.

From the four customer advocacy behaviors discussed in this study, the effect of customer commitment on the support to the company in delivering information (information sharing) (H4a) was not proved. This unproved was based on several causes, customer homogeneity which became the sample in this study is a possible cause, willingness to provide information data has been taken for granted by most of the customers that the majority are customers that have joined the loyalty program of $\mathrm{XYZ}$ cement, therefore providing personal information is considered common thing.

In this study, it was proven that customer commitment affects the marketing research support (H5a) and word-of-mouth referrals (H6a). Companies can take advantage of the willingness of customers to support the research program to identify the needs, expectations and perceptions of product performance. Other behavioral aspect is the willingness of customers in delivering a recommendation or reference of product to the final consumers or fellow sellers. In the cement business, this behavior is the key behavior in increasing sales. Persuasive influence of the building material sellers greatly affects the final consumer in choosing a brand. The advocacy behavior of the final consumer is increased repatronage intentions (H7a). This study found that customers do not only maintain business relations with the company but also increase the level and proportion of purchases in the future activities. These results are consistent with the previous study related to members of loyalty program who had a high level of repeat purchases [32].

The second main research objective of this study was to determine the moderating influence of B2B loyalty program towards supporting customer advocacy behavior. In contrary to the predictions of the B2B loyalty program $(\mathrm{H} 1 \mathrm{~b}-\mathrm{H} 7 \mathrm{~b})$ which are defined in this study, the membership of loyalty program shows no significant moderating effect on the hypotheses model. First, the research found evidence for $\mathrm{H} 1 \mathrm{~b}$ to moderate effect on the relationship between trust and commitment. Second, there was no evidence in supporting $\mathrm{H} 4 \mathrm{~b}$ to how membership in a loyalty program improves customer willingness to share information. Although this hypothesis is rejected, the company get benefit from the loyalty program to help reduce the risk of privacy issues in how the company takes advantage of customers' information specifically. Third, there was evidence of moderating H5B to how membership in a loyalty program positively affects the relationship between customer commitment and support marketing research. Fourth, there was evidence that H6b showed that loyalty program membership has a positive influence on the relationship between the committed customers and their willingness to be engaged in giving references to consumers. Fifth, there was evidence that $\mathrm{H} 7 \mathrm{~b}$ showed that loyalty program membership has a positive influence on the relationship between commitment and the improvement of repatronage intention. Overall, the results of the moderating effect revealed that the loyalty program can become a tool in leading customers to be committed and able to assist the process of strategic marketing in the form of advocacy behavior.

\section{Volume 6 Issue 7, July 2017}




\section{International Journal of Science and Research (IJSR) \\ ISSN (Online): 2319-7064 \\ Index Copernicus Value (2015): 78.96 | Impact Factor (2015): 6.391}

In the condition of the national cement market which is very competitive nowadays, customer trust is not enough to keep the commitment of customers to do business with one kind of brand. Customer satisfaction becomes a seizure under the condition of competition as today, according to the result of this study that belief becomes a mediator variable of the effect of satisfaction on the customer commitment. As well as the discovery of evidence that the role of loyalty programs is not significant in the relationship between the customer satisfaction and the customer trust, which creates challenges for $\mathrm{XYZ}$ cement in maintaining and improving customer satisfaction in terms of products and services given. Its own record for XYZ cement about customer satisfaction regarding payments and promo information offered, these two things are the lowest values of the indicator of customer satisfaction. In the market competition which is growing more competitive, the company should be able to take advantage of the level of customer loyalty which is high enough by offering a payment package and also promo which facilitates retailer customers. Besides that, communication between marketers from companies with retailers need to be upgraded, the track of information should be submitted directly by the company to the retailer customers should be able to be started without having to go through distributors.

Loyalty program that has been running has brought different effects to the company. The test results of independent t-test showed the higher average value is mostly obtained from customers who joined XYZ cement loyalty program. The advantage of loyalty program is also supported by the analysis results of SEM calculation model of the direct effect of the loyalty program, the results of this analysis showed a strong relationship between customer loyalty program to the customer commitment and customer advocacy behavior. This study recommends the XYZ cement company to continue to make efforts in increasing the number of loyalty program members by increasing the benefits for the customer loyalty program members than non-member ones. This finding brings great hope for the XYZ cement company that has run its loyalty program. The high level of trust and commitment to the company is an opportunity for company to make Retailer as the marketer advocate of XYZ cement. The high sense of belonging and attachment of this cement brand can encourage customers to work harder for the benefit of the company and the customers themselves. By knowing the major potential of customers to become advocates in $\mathrm{XYZ}$ cement marketing activities, the strengthening of the loyalty program is necessary. Loyalty program as a medium of communication with customers should be directed to succeed the customer advocacy program. It can be done through training programs or rewarding programs which build the motivation of customers to be advocates. Evaluation of the factors of success for the future of loyalty programs can also refer to the evaluation of customer advocacy activities that have been carried out.

\section{Conclusion}

Customer satisfaction has positive influence on customer trust, which is evidenced by the hypothesis $\mathrm{H} 3 \mathrm{a}$ and this is applied in general for the whole types of customers. There is no difference between the membership status of customer loyalty program and the relationship between customer satisfactions and customer trust $\mathrm{H} 3 \mathrm{~b}$.

Customer trust has a positive influence on customer commitment in establishing a business relationship with the company. It is in line with evidence H1a. In making customers who have commitment to the company, the influence of loyalty program also plays a role in it, it is in line with the proof of $\mathrm{H} 1 \mathrm{~b}$ where customer loyalty programs have a role in the trust relationship on customer commitment. Satisfaction does not have a direct effect to the customer commitment $(\mathrm{H} 2 \mathrm{a})$ but have an indirect effect through the customer trust. Customer satisfaction of the service and cement products does not encourage customers to have a commitment in a relationship, but it requires the evidence of trust so that customers can have a commitment to a particular brand of cement.

The customer commitment has a relationship to the most of customer advocacy behavior such as customer willingness to help marketing research support, giving recommendations about the brand of cement to the final consumers (word of mouth referrals) and increasing the number of purchases and the attention to one cement brand (re-patronage intentions) (H5B, H6b, and H7b). Hence, with a level of customer commitment to the relationship with the brand of $\mathrm{XYZ}$ cement is expected that customers can help the programs of marketers by becoming marketing advocates.

The effects of loyalty program to customer advocacy behavior have been proven by evidence that loyalty programs have a role in the relationship between customer commitment and customer advocacy behavior (H5B, H6b, and H7b) and the evidence that loyalty program directly influences the customer advocacy behavior (H5c, H6c and H7c). From the four advocacy behaviors, there is one behavior that is not proven to be affected by the loyalty program, which is the willingness of customers in conveying information to the company ( $\mathrm{H} 4 \mathrm{~b}$ and $\mathrm{H} 4 \mathrm{c}$ ).

This study becomes a prefix of the research development of the concept in B2B relationship (business to business) on cement commodity in which the nature of customers and market climate are different from other commodities. The development of the further studies is suggested that the analysis to be examined is more diverse and giving out more specific recommendations.

This study used a method of multi-group analysis, which was aimed to determine the effect of moderating variables of loyalty program. With the sample size that is not balanced between the two groups, then the use of multi-group analysis method is not optimal. This study did not use any type of advocacy behavior that can be done by the customers, such as the ability to buy at a higher price, or invest to increase the purchase amount. Thus, in the future studies, the advocacy behaviors can be developed in accordance with the type of business process applied.

Volume 6 Issue 7, July 2017 www.ijsr.net 


\section{International Journal of Science and Research (IJSR) \\ ISSN (Online): 2319-7064}

Index Copernicus Value (2015): 78.96 Impact Factor (2015): 6.391

\section{References}

[1] K.L. KelleR, "Building Customer-Based Brand Equity: A Blueprint for Creating Strong Brands," Marketing Science Institute.Report Summary, 2001.

[2] D.A. Aaker, Managing Brand Equity: Capitalizing on the Value of Brand Names, The Free Pres, New York (US), 1991.

[3] J.N. Kapferer, The New Strategic Brand Management: Creating and Sustaining Brand Equity Long Term, Kogan Page, London (UK), 2004.

[4] K.L Keller, Strategic Brand Management: Building, Measuring, and Managing Brand Equity: Prentice Hall, New Jersey (US), 2003.

[5] P. Kotler, K.L Keller, Manajemen Pemasaran. Ed ke13, Penerbit Erlangga, Jakarta (ID), 2006.

[6] B. Violino, "Building B2B trust," Computerworld, 36(25), pp. 32-35, 2002.

[7] J. Phillips, "Relational Program Effectiveness: The Impact of Reward Type dan Policy on Customer Commitment and Relational Worth," The University of Mississippi, Missisipi, 2007.

[8] R. Lacey, R.M. Morgan, "Customer Advocacy and the Impact of B2B Loyalty Programs," Journal of Business and Industrial Marketing, 24(1): pp. 3-13, 2009.

[9] R.T. Rust, V.A. Zeithaml, K.N. Lemon, Driving Customer Equity: How Customer Lifetime Value is Reshaping Corporate Strategy, Free Press, New York, 2000.

[10] F.R. Dwyer, P.H. Schurr, O. Sejo, Developing buyerseller relationships, Journal of Marketing, 51(2), pp. 1127, 1987.

[11] Moorman, Christine, G. Zaltman, Deshpande, Rohit, "Relationships between providers and users of market research: the dynamics of trust within and between organisations. Journal of Marketing Research," 24(8), pp. 314-328, 1992.

[12] P. Rauyruen, K.E. Meiller, N.J. Barrett, "Relationship Quality as a Predictor of B2B Customer loyalty," Journal of Buseness Research, 60(1), pp. 21-31, 2007.

[13] Dorsch, J. Michael, R. Scott, Swanson, S.W. Kelley, "The role of relationship quality in the stratification of vendors as perceived by customers," Journal of the Academy of Maketing Science, 26(2), pp. 128-42, 1998.

[14] L. Crosby, K. Evans, D. Cowles, "Relationship quality in services selling: An Interpersonal Influence Perspective," Journal of Marketing, 54(3), pp. 68-81, 1990

[15] R.M. Morgan, S.D. Hunt, "The commitment trust theory of relationship marketing," Journal of Marketing. 58(3): pp. 20-38, 1994.

[16] E. Theron, N.S. Terblanche, C. Boshoff, "A managerial framework for relationship," Management Dynamics management in the business-to-business financial services industry, 21(4), 2012

[17] M.Z. Omar, M.N.M Ali, "Brand loyalty and relationship marketing in Islamic banking system. Canadian Social Science," 6(1), pp. 25-32, 2010.

[18] A. Parasuraman, A. Valarie, Zeithaml, L.L. Berry. "Servqual: A Multiple-Item Scale For Measuring
Consumer Perc," Journal of Retailing. 64(1), pp. 12, 1985.

[19] B. Fehr, "Prototype analysis of the concepts of love and commitment," Journal of Personality and Social Psychology, 55, pp. 557-579, 1988.

[20] R. Lacey, J. Suh, R.M. Morgan, "Differential effects of preferential treatment levels on relational outcomes," Journal of Service Research, 9(3), pp. 241-256, 2007.

[21] Allen, J. Natalie, J.P. Meyer, "The Measurement and Antecedents of Affective, Continuance, and Normative Commitment to the Organization," Journal of Occupational Psychology, 63, pp. 1-18, 1990.

[22] Gruen, W. Thomas, J.O. Summers, F. Acito, "Relationship Marketing Activities, Commitment, and Membership Behaviors in Professional Associations," Journal of Marketing, 64(7), pp. 34-49, 2000.

[23] E. Theron, N.S. Terblanche, C. Boshoff, "A managerial framework for relationship," Management Dynamics management in the business-to-business financial services industry, 21(4), 2012.

[24] P. Dabholkar, X. Sheng, "Consumer participation in using online recommendation agents: Effects on satisfaction, trust and purchase intentions," Service Industries Journal, 32(9), pp. 1433-1449, 2012.

[25] abdul muhmin xxxxx

[26] R.E. Spekman, R. Carraway. "Making the transition to collaborative buyer-seller relationships: an emerging framework," Industrial Marketing Management, 35(1), pp. 10-19, 2006.

[27] F.F. Reichheld, W.E Sasser, "Zero defections: quality comes to services," Harvard Business Review, 68(5), pp. 105-111, 1990.

[28] C. Gronroos, "The relationship marketing process: communication, dialogue, and value," Journal of Business \& Industrial Marketing, 19(2), pp. 99-113, 2004.

[29] F.F. Reichheld, W.E. Sasser, "Zero defections: quality comes to services," Harvard Business Review, 68(5), pp. 105-111, 1990.

[30] S.H. Wijanto, "Structural Equation Modeling dengan LISREL 8.8.," Graha Ilmu, Jakarta, 2008.

[31] J.F. Hair, B. Black, B. Babin, R.E. Anderson, Tatham, "Multivariate Data Analysis 6th Edition," Pearson Education, New Jersey, 2006.

[32] Kumar, Nirmalya, K.S. Lisa, J.E. Steenkamp, "The effects of supplier fairness on vulnerable resellers," Journal of Marketing Research, 32(1), pp. 54, 1995.

\section{Author Profile}

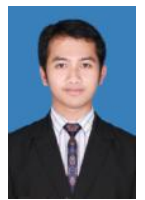

Barikly Robby completed the bachelor degrees in Electrical Engineering from Sepuluh Nopember Institute of Technology in 2012. During 2014-2017, He continued his study on Faculty of Management and Business Bogor Agricultural University and take the marketing topic for the thesis. As a professional profession, He work on one of Cement Company in Indonesia from 2012 until now. 